\title{
Renewable energy and green construction in the Arctic
}

\author{
Violetta Gassiy ${ }^{1 *}$, and Vasiliy Stoikov ${ }^{2}$ \\ ${ }^{1}$ Kuban State University, Public administration department, 350040 Krasnodar Russia \\ ${ }^{2}$ Moscow State University of Civil Engineering (National Research University), 129337, Moscow, \\ Russia
}

\begin{abstract}
In the paper the issues on the renewable energy and green construction in the Arctic are considered. The authors analyze the premises of the green construction in the Northern territories. They propose that the Arctic could be seen as the innovative platform to test the newest technologies for construction and energy generation. The factors impacted on the industrial development are also researched. The authors assess the modern trends of the Arctic construction sphere using the data on housing development, energy consumption etc. They justify that to increase the production of thermal energy in the northern regions of Russia, the green technologies development is the most profitable and long-term. Moreover, the definition of "green technologies" includes not only wooden construction and solar panels, but also many other quite affordable technologies. In the Conclusions the results of the research are performed, including the recommendations on the green construction development considering the specificity of the Arctic territories.
\end{abstract}

\section{Introduction}

Currently, the Arctic is experiencing a third wave of industrial development, being the territory for the implementation of ambitious projects in the field of natural resources (hydrocarbons, non-ferrous and rare-earth metals), as well as the construction of infrastructure. Sustainable development of the Arctic regions of Russia should be based on the transformation of the existing economic structure into an inclusive green economy based on rational environmental management and eco-innovation. The prefabricated housing based on frame construction and innovative methods, as well as the organization of greenhouses, which provide a solution to the problems of food security of the population in the Arctic could be considered as promising in the conditions of the Far North.

In Russia, there is currently a marked increase in the interest of the government in this strategically important region: the programs for new deposits development are being financed, large infrastructure projects are being initiated, and measures are being developed to attract highly qualified personnel. For the effective implementation of the arctic strategy, it is necessary to take into account world trends in the development of the arctic territories

\footnotetext{
* Corresponding author: vgassiy@mail.ru
} 
in terms of focusing on the introduction of innovations, the use of modern technologies for resource conservation and energy efficiency, and the use of alternative energy sources. Of particular importance in these conditions is the green construction, which includes the use of modern materials and technologies suitable for long-term operation in extreme climatic conditions. Green buildings, operating on the principles of resource saving and energy efficiency, help not only reduce the negative impact of construction projects on the environment, but also maintain the health of people operating these objects. In a situation where electric lighting and heating of inaccessible settlements is carried out due to imported energy carriers (for example, diesel), the introduction of solar and wind energy technologies is a significant step to reduce costs and risks. This approach will not only ensure the sustainable functioning of the sensitive Arctic ecosystem and increase the level of environmental safety, but also improve the quality of life of people living in remote areas.

In the field of introducing eco-innovations, the EU experience is significant, where special attention is paid to the Arctic territories, and official documents emphasize their importance for the entire European continent. Experts acknowledge that all countries of the bloc benefit from the socio-economic development of the European Arctic. In particular, the region provides Europe with non-renewable and renewable resources, including renewable energy. Arctic Europe is a space for introducing and testing innovative technologies, business opportunities, applying new management decisions, as well as unique intangible values of nature and culture. Of course, the Arctic is a region well suited for the development, testing and deployment of various innovative technologies, including innovative bio-products, closed-loop systems, and electronic services. Already today, it benefits both technology developers and small remote settlements of northern Europe, the USA and Canada. Positioning the Arctic region as an innovative platform makes it easier for businesses to find their niches in the global and pan-arctic markets. Thanks to ecoinnovation, the idea of a sustainable socio-economic and environmentally sound functioning of sparsely populated and rural territories is being successfully promoted.

\section{The premises for the green construction development in the Arctic}

The Arctic is a strategically important territory. This is confirmed by the fact that every year more and more Arctic and non-Arctic countries seek to strengthen their presence in this region. For example, the White Paper on Arctic Policy was published in China in 2018 [1]. The non-Arctic presence in the Arctic is not only related to mining. Climatic changes leading to transformation of the natural characteristics of the Arctic macro region making the Northern Sea Route accessible year-round. This means the possibility of a faster way from Europe to Asia, a reduction in the delivery time of commercial goods and, in general, significant shifts in the logistics schemes of the global economy.

Currently, experts predict that the efficiency of existing hydrocarbon deposits in the world will decrease by more than $55 \%$ by 2040 . The future of the energy market is associated with the development of new fields in the Arctic. Experts estimate these reserves at 90 billion barrels of oil and 47 trillion cubic meters of gas. Consequently, Arctic projects will be able to maintain the global level of hydrocarbon production in the long term, as well as ensure its growth [2]. Implementation of investment projects in the Arctic takes a very long time. As a rule, it is ten years or more. Therefore, modern Arctic policy should be aimed at infrastructure construction of widespread use, which will become the basis for active development of deposits in the future. Infrastructure development includes the construction of sea and river ports, airports, modern roads, housing that meets the requirements of a harsh climate. 
We believe that housing construction in the Arctic has gone through several historical stages; each of them was characterized by significant transformations in the development of the entire macro region. At the first stage, the settlements consisted of indigenous dwellings leading a traditional lifestyle. As a rule, their activities are related to reindeer herding, hunting, fishing and gathering berries and wild plants. Housing was built in accordance with tradition, using natural materials, including animal skins. The second stage is associated with the beginning of the Arctic industrial development, its resources and natural capital. The appearance on the traditional lands of new people, discoverers, scientists and geologists led to the appearance of houses and other buildings that were temporary or used seasonally.

Later, from the mid-19th century, the third stage began when the industrial development of the Arctic became large-scale and the governments began to implement programs for the exploration and extraction of natural resources. For example, in Soviet times, cities and towns with highly developed social and transport infrastructure were built in the Arctic regions. For example, in Yakutia, in Kular village, founded in 1963, and located next to a large gold deposit, a swimming pool, a dance club and other consumer services functioned. Cause of Arctic industrial development, large cities began to appear on the map, the life of the local population significantly transformed.

The third stage is characterized by the construction of large concrete structures, the use of a large amount of metal. That is why in the Arctic today there is a problem of accumulated environmental damage associated with abandoned equipment, the destruction of reinforced concrete buildings and structures, and a huge amount of scrap metal. In Russia, the Environmental Security Strategy is being implemented, which was adopted in 2017 [3]. One of the priority areas is the elimination of accumulated environmental damage in the Arctic, the collection of solid waste from the activities of industrial enterprises. In recent years, a program for collecting scrap metal on Franz Josef Land has been actively implemented [4]. In 2021, it is planned to implement an environmental campaign to clean the island of Vilkitsky in the Kara Sea. Moreover, much attention is paid to soil restoration, restoration of the landscape disturbed during the Soviet era.

The current fourth stage means that Arctic construction is undergoing changes associated with technological innovation [5]. Such characteristics as energy efficiency, resource saving, fast construction speed, and a full cycle maintenance system become important. During the construction of buildings in the northern regions, more and more attention is paid to such elements as shape, color, roof slope, window layout. Of particular importance is the use of alternative energy sources: solar and wind.

\section{Modern trends in green construction in the Russian Arctic}

An analysis of the experience of green construction in the EU's Arctic countries showed that low-rise residential buildings with energy efficiency and resource saving systems are promising. There are examples of the functioning of houses with a closed life-support system. This practice is widely used in Canada, where a significant part of the settlements is located in the northern latitudes. In fact, low-rise buildings are the basis for a comfortable standard of living. Such houses are quickly built; installation of communications is also facilitated. In Russia, Arctic settlements are dependent on the seasonal import of fuel for boiler houses [6]. Regularly there are situations when, due to deterioration, decay of boiler equipment, accidents occur, that result in breaks in pipelines, heat routes, and therefore diesel fuel used to heat residential buildings is overused. This leads not only to a low level of quality of life, but also poses a threat to the ecology of the Arctic territories.

An alternative is the green building development [7]. However, in Russia today there are no really working tools and mechanisms that stimulate energy-efficient construction in 
the Arctic zone. We believe that a special federal program to improve the energy efficiency of the housing and other Arctic funds should be implemented.

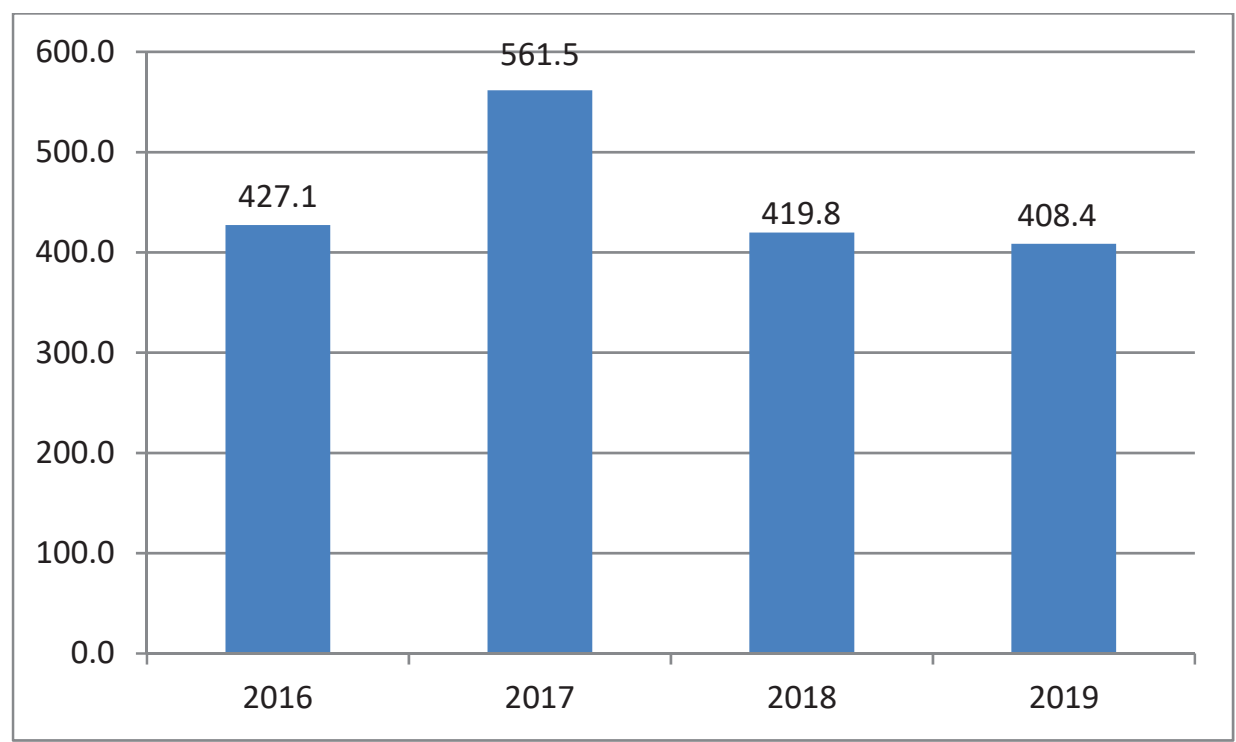

Fig. 1. Housing construction in the Russian Arctic, thousand square meters, Source: Federal State Statistics Service, 2019 [8]

During programs implementation for the housing construction in the Arctic regions, it is necessary to take into account the specificity of the territories, from the features. The Russian Arctic is characterized by a significant amount of dilapidated housing throughout its territory. It is worth noting that despite the high indicators of decay (according to expert estimates more than $60 \%$ ), boiler equipment is modernized annually, and the number of energy sources is increasing, fig.2. [9]

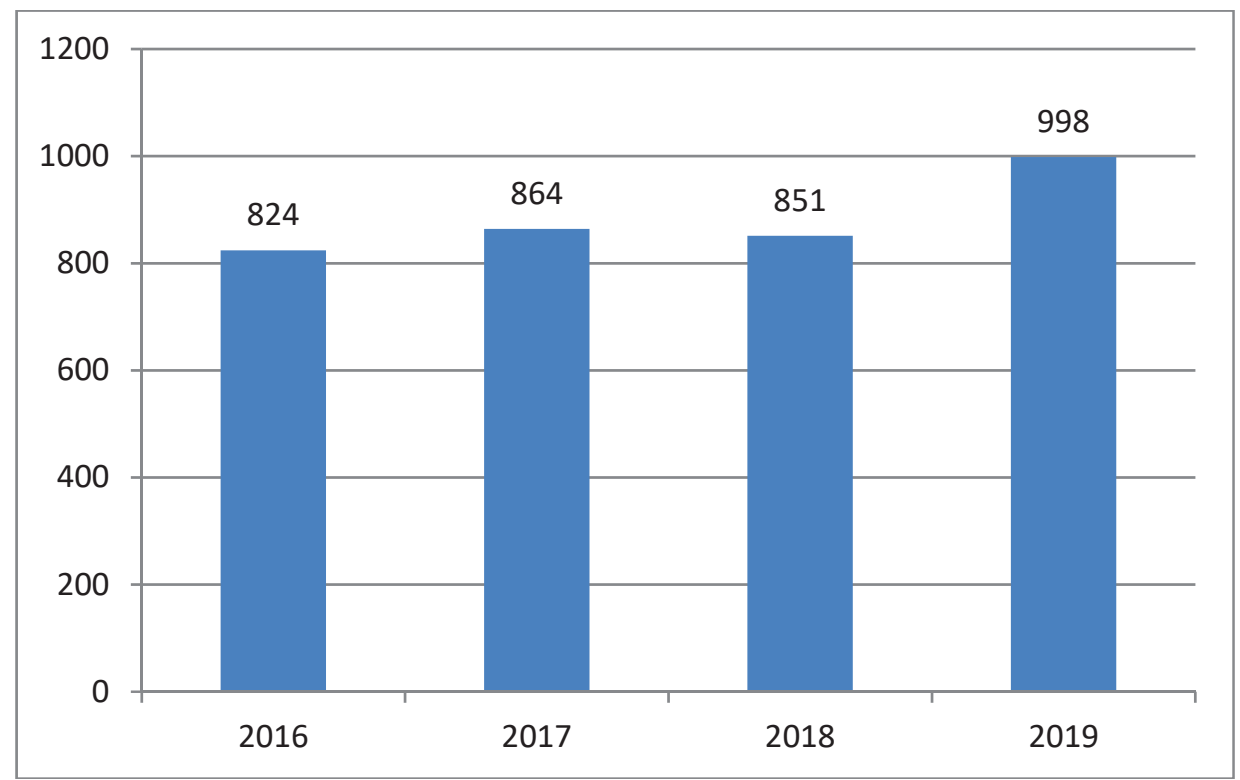

Fig. 2. The number of heat sources, units, Source: Federal State Statistics Service, 2019 
The total capacity of heat sources also remains stably high, fig.3. [10]

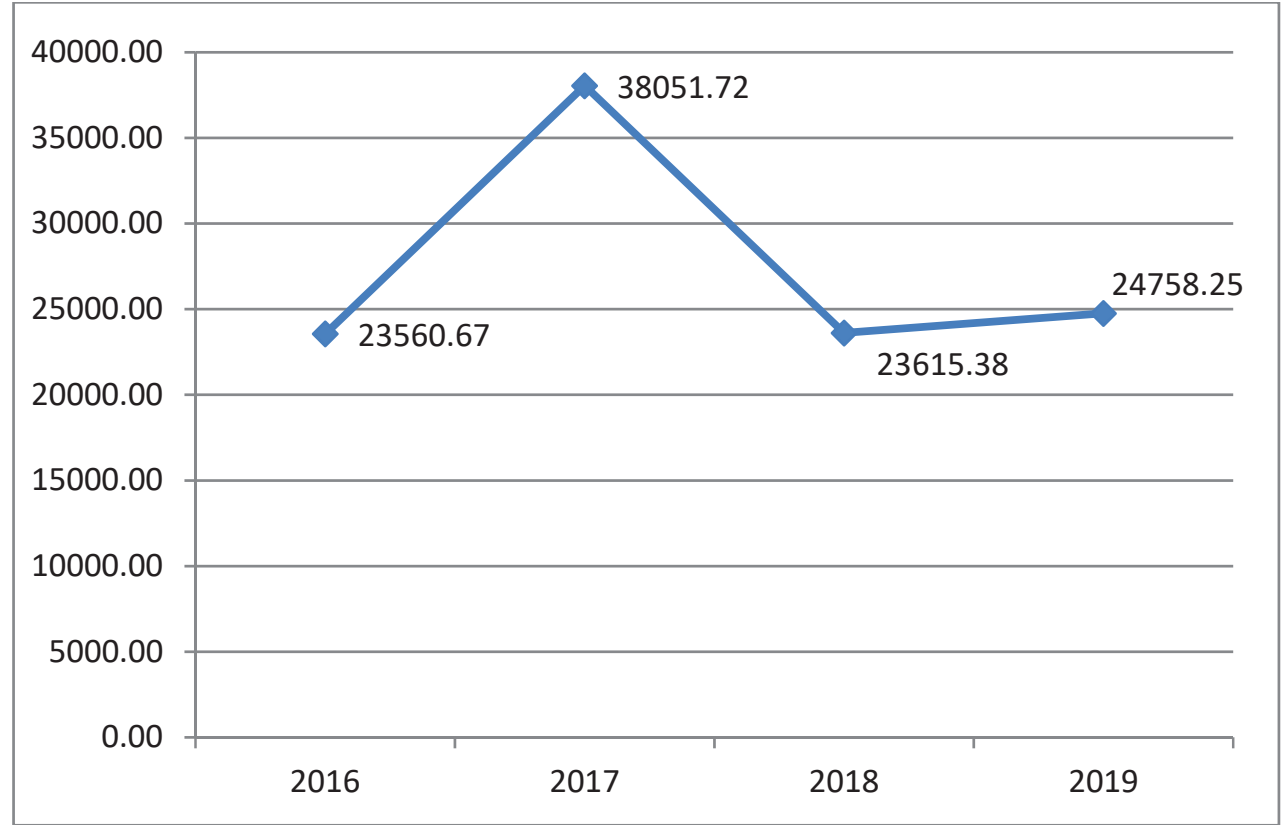

Fig. 3. The total capacity of heat sources, Gcal / h, Source: Federal State Statistics Service, 2019

A social assessment of the situation with the dilapidated housing stock in the North indicates that many citizens living in city centers in worn-out, two-story, chopped-up apartment buildings on wooden stilts do not fully enjoy amenities, but patiently endure difficulties. Their motivation is that they value the familiar comfortable infrastructure of the city center. According to the territorial principle, their children go to good schools, kindergartens, nurseries, in neighboring large supermarkets there are fairly low prices, theaters, museums and other cultural institutions, sports facilities, etc. are located nearby. This factor should be taken into account when planning new construction. This is one of the specific features of housing management in the Arctic territories [11].

To increase the production of thermal energy in the northern regions of the country, the green technologies implementation is the most profitable and long-term. Moreover, the definition of "green technologies" includes not only wooden construction and solar panels, but also many other quite affordable developments. For example, water-based warm floors are becoming increasingly popular in Russia, which make it possible to ensure uniform heating of the entire area with an optimal temperature distribution and a reduction in energy consumption by $6-12 \%$ [12]. This also includes sealed windows with a special coating, which are energy efficient and allow refusing additional heating in winter. In general, green technologies in Russia are developing very slowly. In March 2013, the first national green standard - "Environmental requirements for real estate" was adopted in Russia, and starting from 2019. The use of information modeling technology will become mandatory when constructing facilities under state orders (BIM).

It should be noted that the implementation of construction projects based on energy efficiency and resource saving reduces subsequent energy costs by about 40\% [13]. For example, in Yakutia, in areas where the temperature drops to 50-60 degrees in winter, residents living in smart homes notice a significant reduction in heating and hot water costs. In fact, in such houses, residents pay only for cold water, so the savings in some cases reach 
$50 \%$, and for heating up to $25 \%$. Three-story smart homes have increased insulation, energy-efficient windows are installed everywhere, heat is supplied through autonomous block-modular gas boiler houses. Hot water is heated through solar collectors, and the emergency power supply system is powered by solar panels, all houses also have a supply ventilation system. Another important detail is that the residents of the houses themselves can regulate the microclimate in the apartment. Despite the fact that the cost of building an energy-efficient house is almost 1.5 times higher than the standard one, and reaches full payback after 10 years, the use of new technologies gives its tangible results for the first two to three years of operation of these houses [14].

\section{Conclusion}

Thus, green construction in the Russian Arctic is developing, however, it can be noted that due to a number of objective factors, this process is proceeding at a slow pace. Among the main there are natural or climatic. Construction companies do not have enough time to deliver equipment, construction materials and begin installation of buildings in one season. As the Russian practice of the National project "Housing" shows, it takes at least two years to build smart homes. The lack of equipment and qualified personnel at the location of the proposed construction also forces the developer to seek solutions and incur additional costs. There is also a negative factor of more global nature. It is a climate change. Existing standards for the construction of buildings in the Arctic territories were developed in Soviet times in the 1980s. Then the temperature at a depth of 10 meters was approximately -6 degrees. Currently, experts note that the temperature has increased significantly and it is now about -1.5 . Seasonal processes of thawing and freezing of the permafrost layer destroy reinforced concrete piles, which are used in the construction of the foundation. There are examples of Norilsk, Yakutsk, where buildings are considered unsuitable for life as a result of the destruction of the foundation. In this case, taking into account the changes that are taking place, it is necessary to introduce new, lighter materials and structures for the construction of buildings in permafrost conditions. Therefore, the development of the Arctic is a complex process, associated not only with the development of innovations in the field of geological exploration and mining, but also with the introduction of the principles of a green economy, primarily in the construction sector.

The paper was prepared by the financial support of the grant of the President of the Russian Federation for state support of young Russian scientists - doctors MD-402.2019.6.

\section{References}

1. The State Council Information Office of the People's Republic of China, China's Arctic

Policyhttp://english.www.gov.cn/archive/white_paper/2018/01/26/content_281476026 660336.htm (2018).

2. M. E. Brownfield et al., "An Estimate of Undiscovered Conventional Oil and Gas Resources of the World," U.S. Geological Survey, USGS Fact Sheet 2012-3024 (2012)

3. Ministry of Natural Resources and Ecology. The environmental safety strategy of the Russian Federation for the period until 2025. http://www.mnr.gov.ru/docs/strategii_i_doktriny/142854/ 
4. A. Khaiter Peter, Marina G. Erechtchoukova, Sustainability Perspectives: Science, Policy and Practice: A Global View of Theories, Policies and Practice in Sustainable Development, Strategies for Sustainability, 347 P. (2019).

5. D. L. Gautier, K. J. Bird, R. R. Charpentier, A. Grantz, D.W. Houseknecht, T.R. Klett, T.E. Moore, J.K. Pittman, et al. Assessment of undiscovered oil and gas in the Arctic. Science, 324, p 1175-1179. (2009)

6. Decree of the President of the Russian Federation dated 03/05/2020 No. 164 "On the Basics of State Policy of the Russian Federation in the Arctic for the Period Until 2035" / State system of legal information. URL: http://publication.pravo.gov.ru/Document/View/0001202003050019.

7. Krivovichev Sergey V. Arctic Mineral Resources: Science and Technology, Minerals, 9, 192; doi:10.3390/min9030192 (2019).

8. Housing construction in the Russian Arctic / Federal State Statistics Service, 2019. URL: https://www.gks.ru/free_doc/new_site/region_stat/calendar1-2020.htm

9. The number of heat sources/ Federal State Statistics Service, 2019. URL: https://www.gks.ru/free_doc/new_site/region_stat/calendar1-2020.htm

10. The total capacity of heat sources/ Federal State Statistics Service, 2019. URL: https://www.gks.ru/free_doc/new_site/region_stat/calendar1-2020.htm

11. Anne Tolvanena, Pasi Eilu, Artti Juutinena Katja Kangasa Mari Kivinen Mira Markovaara-Koivistoc Arto Naskalie, Veera Salokannel, SeijaTuulentie, JukkaSimila. Mining in the Arctic environment - A review from ecological, socioeconomic and legal perspectives, Journal of Environmental Management, 233, 832-844. https://doi.org/10.1016/j.jenvman.2018.11.124 (2019)

12. Violetta Gassiy, Vasiliy Stoikov, Development of a green economy and environmentally friendly business in Russia, E3S Web Conf., 110, 02069 https://doi.org/10.1051/e3sconf/201911002069 (2019)

13. Law KS, Roiger A, Thomas JL, et al. Local Arctic air pollution: Sources and impacts. Ambio; 46 (Suppl 3): 453-463. doi: 10.1007 / s13280-017-0962-2 (2017).

14. V. Gassiy, Protecting indigenous rights from mining companies the case of ethnological expertise in Yakutia, Sibirica, 18, 3, pp. 92-108 (2019). 